Ege Tıp Dergisi / Ege Journal of Medicine 2020; 59 (2): 136-139

\title{
Olgu sunumu: Atipik özellikli demans ve duygulanım bozukluk birlikteliği
}

\section{Case report: An atypical presentation of dementia with affective disorder}

\author{
Fatma Özge Kayhan Koçak ${ }^{1}$ (D) Gülser Karakoç ${ }^{2}$ (D) \\ Bahattin Gökdemir ${ }^{1}$ (D) \\ Sevnaz Şahin ${ }^{1}$ \\ Sercan Şahutoğlu ${ }^{1}$ (D) \\ Seval Ay \\ Zeliha Fulden Saraç ${ }^{1}$ \\ ${ }^{1}$ Ege Üniversitesi Tıp Fakültesi İç Hastalıkları Ana Bilim Dalı/Geriatri Bilim Dalı, İzmir, Türkiye \\ ${ }^{2}$ Ege Üniversitesi Tıp Fakültesi Psikiyatri Ana Bilim Dalı, İzmir, Türkiye
}

Öz

Psikoz, düşünce ve algının ağır oranda bozulduğu zihin durumunu tanımlamakta kullanılan genel bir psikiyatri terimidir. Psikotik epizot geçiren hastalar halüsinasyonlar görebilirler, delüzyonel inançlar taşıyabilirler, kişilik değişiklikleri ve düşünce bozukluğu gösterebilirler. Psikozun ileri yaşta başlaması daha nadir görüldüğünden; özellikle halüsinasyon, delüzyonel inançlar, kişilik değişiklikleri ve düşünce bozukluğu ile başvuran ileri yaştaki kişilerde ayırıcı tanıda psikoz tanısının yanı sıra depresyon ve demans tanıları da düşünülmelidir. Bu vakada, taktil halüsinasyonla başvuran, depresyonun eşlik ettiği 85 yaşında demans hastası sunulmuştur. Vücutta karıncalanma ve sürekli pirelerin ısırdığını hissetme şikâyeti ile başvuran erkek hastaya, fizik ve psikiyatrik muayene ile kapsamlı geriatrik değerlendirme sonrası psikotik bulgulu depresyon ve demans tanısı konmuştur. Hekim tarafından ileri yaştaki her hasta demansiyel süreç açısından değerlendirilmeli ve demansiyel duruma başka psikiyatrik hastalıkların eşlik edebileceği göz önünde bulundurulmalıdır.

Anahtar Sözcükler: Demans, depresyon, ileri yaş.

\begin{abstract}
Psychosis is a general psychiatric definition used in different psychiatric disorders with severe disruption in thought and perceptions. Patients with psychotic episodes may have hallucinations, delusional beliefs and disorientation. They may show changes in personality. Since onset of psychosis occurs rarely in old age, depression and dementia should be primarily considered especially in elderly patients presenting with hallucinations, delusional beliefs, personality changes and thought disorder. We present a case report of patient with dementia and late onset depression presenting with tactile hallucination. The aim of this case presentation is to focus on the hazards of symptom-based diagnosis and treatment that may cause misdiagnosis in elderly patients. An 85-year-old male patient was admitted to outpatient clinic with a complaint of tingling in his body and the feeling of insects crawling underneath your skin. After physical examination and comprehensive geriatric assessment, psychiatric consultant evaluated patient in Geriatric Medicine department. He was diagnosed with psychotic depression and dementia. Every patient should be examined for the cognitive impairment by the physician. It should also be considered that other psychiatric disorders may accompany by the dementia.
\end{abstract}

Keywords: Dementia, depression, elderly.

\footnotetext{
Sorumlu yazar: Fatma Özge Kayhan Koçak

Ege Üniversitesi Tıp Fakültesi İç Hastalıkları Ana Bilim

Dalı/Geriatri Bilim Dalı, İzmir, Türkiye

E-posta: drozgekayhankocak@gmail.com

Başvuru tarihi: 05.07.2019 Kabul tarihi: 17.01.2020
} 


\section{Giriş}

Psikoz, düşünce ve algının ağır oranda bozulduğu zihin durumunu tanımlamakta kullanılan genel bir psikiyatri terimidir. Psikotik epizot geçiren hastalar halüsinasyonlar görebilirler, grandiyöz (büyüklük/yücelik) veya paranoid sanrılar gibi sanrısal (delüzyonel) inançlar taşıyabilirler, kişilik değişiklikleri ve düşünce bozukluğu gösterebilirler. Psikozun ileri yaşta başlaması daha nadir görüldüğünden; özellikle halüsinasyon, delüzyonel inançlar, kişilik değişiklikleri ve düşünce bozukluğu ile başvuran ileri yaştaki kişilerde ayırıcı tanıda psikoz tanısının yanı sıra depresyon ve demans tanıları da düşünülmelidir.

Sanrı; neredeyse herkesin inandığı dış gerçeklik hakkında sıkı sıkıya bağlı kalarak sürdürülen yanlış çıkarımların olmasıdır. Varsanım ise mevcut olmadığı halde kişinin gerçek olduğuna inandığı bir dış uyaranı algılamasıdır (1). Varsanım genelde görsel ve işitsel olmakla birlikte nadiren somatik, taktil (dokunma ile ilgili) ve kokusal olabilir. Psikozdaki en önemli fark, bunun gerçekçiliğine karar verecek mekanizmanın zayıflamasıdır (2). İleri yaş (geriatrik) grubunda bu mekanizmayı zayıflatan en önemli hastalıklardan biri kognitif bozukluk diğeri ise depresyondur.

$\mathrm{Bu}$ vakada, 85 yaşında taktil varsanımla başvuran, geç tanı konulan depresyona ikincil demans hastası sunulmuştur. Vakayı sunmaktaki amacımız; ileri yaştaki hastaların semptom odaklı tedavi edilmesi, altta yatan tedavi edilebilen hastalıkların tanısında geç kalınmasına ve bu durumun komorbidite artışına neden olabileceğini göstermektir.

\section{Olgu Sunumu}

Eskiden çiftçi olan, 85 yaşında, diplomasız okur yazar erkek hasta, vücutta karıncalanma ve pire ısırığı hissi şikâyeti ile başvurdu. Bu şikayetler üç yıl önce başlamış son altı ayda giderek artmıştı; sürekli olarak gözünün içinde, sırtında göremediği bir şeylerin gezdiğini hissettiğini, aralıklarla ısırık hissi yaşayıp çığıı attığını ve kaşıntı nedeniyle artık geceleri hiç uyuyamadığını ifade etmekteydi. Anamnez ve muayene sonunda hastada taktil varsanım ve depresif duygu durumun olduğu belirlendi. Sigara, alkol, madde alım öyküsü olmayan hastanın; özgeçmişinde çeşitli merkezlerde psikoz tanısı ile son üç yıldır ara ara antipsikotik ilaç kullandığı ancak yanıt alamadığı için kullanmayı bıraktığı öğrenildi. Hastanın ve yakınlarının verdiği bilgiye göre daha önce depresyon atağı geçirmemiş, bu nedenle hiç tedavi almamıştı. Soy geçmişinde özellik yoktu. Hastanın tedaviye karşı şüpheciliğinin olması ve bu zamana kadar ayaktan tedavi uyumunun sağlanamamış olması nedeniyle kliniğine yatırılarak ileri tetkik ve tedavi planlandı. Hastada fizik muayene normal sınırdaydı. Ajitasyonu belirgindi, duygu durumu depresif; anksiyete ve anhedonisi ön planda idi. Taktil varsanıma, nihilistik (böceklerin iç organlarını ele geçirdiği ve yok edeceği düşüncesi) ve somatik sanrı (böceklerin hastayı içten dürttüğü düşüncesi) eşlik ediyordu. İştahı normal olan hastanın, başlangıç (uykuya dalmada zorluk) ve sürdürüm insomniası (uykusuzluk) mevcuttu. Intihar veya adam öldürme (homisit) düşüncesi olmayıp çağrışımları olağandı. Günlük Yaşam Aktiviteleri Testi (6/6) ve Lawton-Brody Enstrümental Günlük Yaşam Aktivite Skalası (14/14) tam puan olarak hesaplandı. Hastanın ve yakınının unutkanlıkla ilgili bir şikayetinin olmadığı yönünde bilgi vermesine rağmen yapılan Mini Mental Durum Testinde (MMDT) (13/30) hafıza, hatırlama, dikkat ve hesaplama alanlarından hiç puan alamadı. Yesavage geriatrik depresyon skalası- kısa form (GDS-KF) $(0 / 15)$ normal saptandı. Laboratuvar tetkiklerinde patoloji saptanmadı. Kraniyal Manyetik Rezonans görüntülemesi kronik iskemik değişiklikler olarak raporlandı. Hasta Psikiyatri Anabilim Dalı ile birlikte değerlendirildi. MMDT'i orta demans ile uyumlu gelen hasta Klinik Demans Derecelendirmesi (CDR) yapıldığında 1- hafif bozukluk olarak tanımlandı, bu uyumsuzluğun hastanın eğitim seviyesi ile ilgili olabileceği düşünüldü. GDS-KF sonucu depresyon ile uyumlu gelmemesine rağmen hastada depresif duygu durumu gözlenmekteydi. İleri yaş grubunda depresyon varlığı daha çok somatizasyon ile kendini gösterdiği ve hastalığı yadsıma ile sık karşılaşıldığı göz önüne alınarak hasta psikotik bulgulu depresyon ve demans olarak kabul edildi; sertralin 50 mg, olanzapin 2,5 $\mathrm{mg}$ ve donepezil $5 \mathrm{mg}$ başlandı. Takibinde taktil varsanımı ve depresif duygu durumunun devam etmesi üzerine tedavisine risperidon $1 \mathrm{mg}$ eklendi. Hastanın tedavi uyumu görüldükten sonra taburcu edildi. Bir ay sonra poliklinik kontrolünde değerlendirilen hastanın depresif duygu durumunun ve psikotik semptomlarının gerilemiş, duygulanımının rahatlamış, uykusunun daha düzenli olduğu görüldü. Yakın hafızadaki 
bozukluğun hala devam ettiği fakat dikkat süresinin daha iyi olduğu görüldü. Depresyon tedavisi üç aya tamamlandığında MMDT'nin tekrar yapılması planlandı.

\section{Tartışma}

İleri yaşta psikotik belirtilerle başvuran hastalarda; ilaç yan etkileri, deliryum, demansiyel süreç, geçmiş/şimdiki psikotik epizot ya da depresyon gibi hastalıklar ayırıcı tanıda düşünülmelidir. İlk dışlanması gereken durum deliryumdur; tanı deliryum lehine ise buna neden olabilecek altta yatan bir durum araştırılmalıdır (3). Hastamızda yer zaman oryantasyonunun tam ve gün içinde bilinçte dalgalanmanın olmaması nedeniyle ön planda deliryum düşünülmedi. Deliryum dışlandıktan sonra yapılması gereken ikinci adım demans ya da diğer psikiyatrik hastalıkların ayırıcı tanısıdır. Bazen semptomların iç içe geçmesi ya da eşlik eden diğer hastalıkların varlığı nedeniyle ayırıcı tanı yapmak zorlaşabilmektedir. Hastamızda demans veya depresyondan hangisinin öncelikli olarak davranışsal bozukluğa neden olduğu saptanmakta zorlanılmıştır. $\mathrm{Bu}$ amaçla aile üyeleriyle birçok kez ayrıntılı görüşme yapılmıştır. Aile bireyleri tarafından, üç yıl önce çalışmayı bıraktıktan sonra sosyal çevresinden uzaklaştığı, böceklerin iç organlarını ele geçirdiği, yok edeceği ve kişiyi içten dürttüğünü söyleme gibi tuhaf davranış ve konuşmalarının başladığı ifade edildi. Bu bilgiler ışığında demansiyel süreci net anlaşılamamış olsa da psikotik bulguların depresyon sonrası ortaya çıktığı saptanmıştır. Ayrıca bu vakada olduğu gibi, depresyonda çoğunlukla duygu durumla uyumlu, özellikle bedenle ilgili nihilistik (inkâr) sanrılar görülürken, demansta çoğunlukla paranoid içerikli sanrıların görülmesi beklenir. Son 6 ayda şikayetlerin arttığı, ilk şikayetlere kayıtsızlığın (apati) eşlik etmediği göz önüne alındığında, tedavi edilmeyen depresyonun kognitif yıkıma yol açarak demans gelişmesine yatkınlık yarattığı ve eklenen demans tanısı ile psikotik bulguların daha çok alevlendiği düşünülmüştür.

Psikotik belirtilerle gelen hastalarda bir diğer ayırıcı tanı şizofrenidir. Şizofreni en geç 40'lı yaşlarda tanı almakta, daha ileri yaşlarda başlangıç nadiren görülmektedir. 65 yaşından sonraki olgular genelde çok geç başlangıçı şizofreni benzeri psikoz (very late-onset schizoprenia-like psychosis-VLOSLP) olarak isimlendirilmekte ve kalıtsal olmayıp demans ile ilişkilendirilmektedir (4). Hastamızda VLOSLP'de daha sık görülen perseküsyon ya da referans sanrıları yokken; yapılan psikiyatrik muayene demans ve psikotik özellikli depresyon ile uyumlu saptandı. Hastamızda aile öyküsünün olmaması, şikayetlerinin sadece son üç yılda olması, özgeçmişinde şizofreniyi işaret edecek hiçbir öyküsünün bulunmaması ve şizofrenide görülen negatif bulguların yokluğu; şizofreni tanısını dışlamamıza yardımcı olmuştur (5). Ek olarak şizofreni hastalarında daha yüksek dozlarda antipsikotik tedavinin daha uzun tedavi süreleri sonrasında klinik yanıt görülmektedir (6); hastamızda düşük doz antipsikotik tedavi ile dört hafta gibi kısa bir sürede yanıt alınmıştır.

Varsanımlar gerek hastalar gerekse bakım verenlerde yaşam kalitesinde düşmeye ayrıca bakıcı depresyonuna ve hastane/huzurevi başvurularında artışa neden olmaktadır (7). Hastamızda da taktil halüsinasyonlar aile ilişkilerinin zayıflamasına neden olmuştur ve aile desteğini kaybetmesi nedeniyle uzun süredir hastaneye tek başına geldiği öğrenilmiştir. Aile desteğinin kaybolması depresif ruh durumunu daha da arttırmıştır. Hastamızda demans ve depresyon tedavisinin eklenmesi ile birlikte kısa sürede oğluyla ilişkisi düzelmiş, sosyal çevresine tekrar uyum sağlamıştır.

Varsanımların genellikle rasgele değil, bazı tecrübelerle ilgili olduğu düşünülmektedir (8). Daha önce tifo geçiren hastamız bu hastalığın böceklerle kapıldığına inanmaktaydı ve hala vücudunda olan bu böcekler yüzünden böyle hissettiğini düşünmekteydi. Kliniğimize başvurana kadarki sürede farklı merkezlere (enfeksiyon hastalıkları kliniği, iç hastalıkları kliniği) bu nedenle başvurmuş ve birçok kez normal çıkan tetkiklere rağmen hasta aksine inandırılamamıştır. Hastane arşivine bakıldığında da iki yıl önce enfeksiyon hastalıkları kliniğinde enfeksiyöz etkenlerin araştırılması açısından yatırıldığı, yapılan tetkik ve kültürlerinde herhangi bir patoloji saptanamadığı görülmüş, fakat hastanın psikiyatrist tarafından o dönem önerilen tedaviyi uygulamadığı görülmüştür.

Taktil varsanımlara genelde görsel varsanımların da eşlik edebileceği bilinmektedir. Fakat olgumuzda farklı olarak böceklerin gezdiğini hissederken hasta özellikle böcekleri hiç görmediğini, sadece cildinin altında gezdiklerini hissettiğini ifade etmiştir. Bu ayrıntıya daha detaylı bir anamnez ile ulaşılabilmiştir. Bu durum ileri yaştaki hastaların daha uzun muayene 
süresine ihtiyacı olduğunu göstermektedir; özellikle demans düşünülen hastaların acele etmeden değerlendirilmeli, bu hastalarla daha uzun görüşmeler yapılmalıdır.

Depresyon ile demans arasındaki ilişki tam anlamıyla açıklanamamıştır. Genç yaşlarda görülen depresyon varlığı, demans için bir risk faktörü olarak tanımlanırken; ileri yaşta görülen depresyonun demansın bir belirtisi olabileceği düşünülebilir (9). Özellikle ileri yaşta görülen ilk depresif duygu durumunun, demans bulgusu olabileceği akılda tutulmalıdır (9).

Toplumda inanılanın aksine unutkanlık yaşlanmanın doğal bir sonucu değildir. Bu nedenle hekim tarafından her 65 yaş üstü hasta işlevsel bozulma olmasa dahi hem demansiyel süreç açısından taranmalıdır hem de demansiyel duruma başka psikiyatrik hastalıkların eşlik edebileceği göz önüne alınarak ek hastalıklar açısından da değerlendirilmeli, gerekli hallerde psikiyatri kliniğiyle iş birliği içinde olgular değerlendirilmelidir. Ayrıca depresyonun ileri yaşta somatizasyon ile kendini gösterebileceği ve tedavi edilmezse bilişsel gerilemeye yol açabileceği unutulmamalıdır.

Çıkar çatışması: Yazarlar çıkar çatışması beyan etmemişlerdir.

\section{Kaynaklar}

1. American Psychiatric Association, Diagnostic and Statistical Manual of Mental Disorders. Fifth ed. American Psychiatric Publishing, Arlington, 2013: 87-88.

2. Lincoln TM, Mobius C, Huber MT, Nagel M, Moritz S. Frequency and correlates of maladaptive responses to paranoid thoughts in patients with psychosis compared to a population sample. Cogn Neuropsychiatry 2014; 19 (6): 509-26.

3. Brendel RW, Stern TA. Psychotic symptoms in the elderly. Prim Care Companion J Clin Psychiatry 2005; 7 (5): 238-41.

4. Cort E, Meehan J, Reeves S, Howard R. Very Late-Onset Schizophrenia-Like Psychosis: A Clinical Update. Journal of psychosocial nursing and mental health services 2017; 56 (1): 37-47.

5. Palmer BW, Mcclure FS, Jeste DV. Schizophrenia in late life: findings challange traditional concepts. Harv Rev Psychiatry 2001; 9 (2): 51-8.

6. Jeste DW, Finkel SI. Psychosis of alzheimer's disease and related dementias. Diagnostic criteria for a distinct syndrome. Am J Geriatr Psychiatry 2000; 8 (1): 29-34.

7. El Haj M, Roche J, Jardri R, Kapogiannis D, Gallouj K, Antoine P. Clinical and neurocognitive aspects of hallucinations in Alzheimer's disease. Neurosci Biobehav Rev 2017; 83: 713-20.

8. Moritz, S, Goritz, AS, Gallinat J et al. Subjective competence breeds overconfidence in errors in psychosis. A hubris account of paranoia. J Behav Ther Exp Psychiatry 2015; 48: 118-24.

9. Rubin, R. Exploring the relationship between depression and dementia. Jama 2018; 320 (10): 961-2. 